\title{
Can Business-Oriented Managers Be Effective Leaders for Corporate Sustainability? \\ A Study of Integrative and Instrumental Logics
}

\begin{abstract}
This qualitative study investigates whether the views of managers need to be congruent with the corporate sustainability (CS) logics—either integrative or instrumental—of their employing organization. We assessed the CS performance of 25 organizations within the Australian forestry and wood products industry and analyzed the CS orientations of 32 senior managers within these companies to explore whether their individual CS views are consistent with organizational CS logics. The findings indicate that, in general, better performing organizations are led by managers that hold the integrative view, while poorer performing organizations are more likely to have managers with an instrumental view of CS.

Nonetheless, there were noteworthy exceptions to this conclusion. The findings indicate that, under certain industry conditions, managers who hold an instrumental view may be able to generate ecological and social organizational outcomes that are at least equal to those produced by integrative managers.
\end{abstract}

KEYWORDS: corporate sustainability; environmental management; integrative view; instrumental view; leadership; sustainable development. 


\section{Can Business-Oriented Managers Be Effective Leaders for Corporate Sustainability? A Study of Integrative and Instrumental Logics}

Corporate sustainability research examines the ways in which the concept of sustainable development can be applied to organizational settings (Bansal, 2005; Dyllicks and Hockerts, 2002). Debate continues regarding the various paradigms, concepts, methods, and strategies that businesses can and ought to adopt in order to achieve sustainable outcomes (Borland et al., 2016; Ivory and Brooks, 2018; Marcus and Fremeth, 2009; Siegel, 2009; Xie and Hayase, 2007). Recent theoretical developments in particular link the integrative view of corporate sustainability to effective social and environmental outcomes in business (Gao and Bansal, 2013; D. Jones, 2016). An integrative view proposes the concurrent advancement of all three sustainability priorities - economic, social, and environmental (Le Roux and Pretorius, 2016). It differs in perspective and application from the instrumental view, which reflects an anthropocentric, economics-based rationale for sustainability, usually linked to degraded environmental, social, and economic outcomes for business (Borland and Lindgreen, 2013; Hahn and Figge, 2011; Purser et al. 1995). Theoretical examinations of these two logics - the integrative and instrumental views - are extensive, but few empirical studies explore how their dynamics play out in practice.

The superiority of the integrative view was suggested by Gao and Bansal (2013), who analyzed 738 organizations over 13 years and identified separate integrative and instrumental logics for pursuing corporate sustainability. Although conceived at the organizational level, this framework has also served as an explanatory tool for managerial behavior (Hahn et al., 2015; Montabon et al., 2016), despite the absence of individual-level factors in prior theoretical studies. Little is known about the executives and middle managers who run 
integrative organizations that generate strong environmental and social contributions, or the instrumental organizations that perform lower on social and environmental measures. Are socially and environmentally inclined organizations always run by executives with an integrative logic? Conversely, are organizations that perform lower on sustainability measures always run by instrumental executives? Little is known about whether the integrative and instrumental typologies translate to the individual level, or whether instead, contradictions exist between the organization's approach and the individual manager's orientation.

To understand the relevance of the two distinct logics at firm and individual levels of analysis, we adopt a multilevel approach to theory and research in organizations, consistent with Kozlowski and Klein (2000). We start with a review of literature surrounding the integrative and instrumental views of corporate sustainability, also examining related business and normative motives that may drive executives and managers. We then describe and explain the methodology we used to collect primary and secondary data about 25 forestry organizations in Australia, and 32 senior and middle managers heading these companies. Next, we provide qualitative and quantitative evidence which examines the overall approach and performance of each organization, supplemented with qualitative data describing the orientations of the managers running these companies.

In a nutshell, the results provide empirical support for the integrative and instrumental views of corporate sustainability at both organizational and individual levels of analysis. However, due to the study identifying several instrumental managers leading organizations that both espouse and generate strong social and environmental outcomes, new insights are offered into the empirical discrepancies between views at organizational and individual (managerial) levels. Initial suggestions are offered to explain these interesting findings, which indicate that, in certain scenarios, instrumental managers may be motivated to lead and 
generate strong social and environmental performance, in line with their integrative counterparts. The findings question mainstream assumptions about the motivational underpinnings of corporate sustainability, while also highlighting interesting implications for organizations aiming to excel in corporate sustainability.

\section{Integrative and Instrumental Corporate Sustainability}

The application of sustainability and sustainable development to organizational practice (Montiel, 2008; Russo, 2003) entails intergenerational aspects and expectations that companies that engage in corporate sustainability make long-term contributions, in the form of nonfinancial outcomes (Hart and Dowell, 2011). Organizations and individual actors are embedded in broader systems, such as the natural environment and stakeholder groups (Whiteman et al., 2013). In its application, corporate sustainability generally focuses on the development of strategies and practices so that the three pillars of social, environmental, and economic sustainability are integral elements of — rather than add-on supplements toorganizational decision making (Angus-Leppan et al., 2010).

However, corporate sustainability can also be delineated according to a conservative view in which businesses merely seek to avoid negative social and environmental externalities and outcomes (Carpenter and White, 2004) versus a progressive view, such that companies actively seek to add social and environmental value (Baumgartner and Ebner, 2010). These divergent logics are also referred to as the instrumental and integrative views of corporate sustainability (Gao and Bansal, 2013). An instrumental logic adopts economic reasoning (the business case) to implement environmental and social agendas; the integrative logic regards all three sustainability pillars as equally and simultaneously important, typically taking a normative position toward organizational applications.

\section{The Instrumental View}


The instrumental view favors the economic dimension over the social and environmental and, consequently, tends to exclude situations in which environmental and social value does not align with economic improvement (Gao and Bansal, 2013; Siegel, 2009). This view also indicates that business should benefit economically from its social and environmental activity (Delmas and Blass, 2010; Hahn and Figge, 2011). The business case (Salzmann et al., 2005) is preceded by a cost-benefit analysis, which is seeking financial returns from environmental and social investments rather than integrating these concerns into business operations (Carroll and Shabana, 2010; Kleine and von Hauff, 2009; Margolis and Walsh, 2003). It also focuses on outcomes such as increased legitimacy, generating competitive advantages, and synergistic value creation (Carroll and Shabana, 2010). The instrumental view is dominant in fields such as instrumental stakeholder theory (Donaldson and Preston, 1995; T. M. Jones, 1995) and the resource-based view of the firm (Barney, 1991; Barney et al., 2001; Hart and Dowell, 2011; Orlitzky et al., 2011; Russo and Fouts, 1997; Wernerfelt, 1984). In addition to receiving substantial attention in prior literature (Carroll and Shabana, 2010; Gao and Bansal, 2013; Salzmann et al., 2005), the instrumental view reflects many applications of corporate sustainability in practice, in that businesses commonly favor economic over social and environmental priorities (Ehnert et al., 2014).

In turn, the instrumental view has widely shaped the corporate sustainability agenda. Significant research explores the financial benefits of pursuing social and environmental performance (Barnett and Salomon, 2012; Dixon-Fowler et al., 2013; Eccles et al., 2014; Hart and Ahuja, 1996; Orlitzky et al., 2003; Wang et al., 2014), though the conclusions vary. Some studies reveal a positive link of social and environmental performance with financial performance (Charlo et al., 2015; Dixon-Fowler et al., 2013; Eccles et al., 2014; Endrikat et al., 2014; Friede et al., 2015; Orlitzky et al., 2003), but most research argues for a complex relationship in which the positive link depends on moderating and mediating factors, such as 
environmental performance (reactive vs. proactive), firm characteristics (large vs. small firms), methodological and measurement issues (Dixon-Fowler et al., 2013), and the multidimensionality of the focal constructs (Endrikat et al., 2014). Meta-analyses also integrate evidence about these relationships; for example, one psychometric meta-analysis suggests that reputation-related aspects of corporate virtue, manifested as corporate social responsibility, pay off for companies (Orlitzky et al., 2003). Barnett and Salomon (2012) and Trumpp and Guenther (2017) suggest that this relationship may not be linear, but rather Ushaped, such that both low and high corporate sustainability performers achieve better financial returns, whereas moderate performers achieve lower returns. Another study suggests that market value is not generated through corporate sustainability activities, but rather that the market punishes poor sustainability performers (Lourenço et al., 2011). Although this debate continues, instrumentalism provides a relatively narrow view on the financial implications of social and environmental practices, which runs the risk of diverting from the central purpose of corporate sustainability (Epstein, 2008; Marcus and Fremeth, 2009).

\section{The Integrative View}

In parallel with theory development focused on the instrumental view, a growing body of literature adopts a normative perspective, asserting that social and environmental priorities should to be considered on equal footing with economic considerations. Critics of the instrumental view note that failing to balance these priorities equally results in unsustainable activity (Gao and Bansal, 2013; Hahn et al., 2015). This equal application of corporate sustainability priorities, or the integrative view, has gained prominence more recently. It rejects the anthropocentric worldview of the instrumental logic and replaces it with an interconnected perspective on the business entity, which is firmly lodged within natural and social environments (Gao and Bansal, 2013; Garriga and Melé, 2004). This view represents a response to the alleged shortcomings of the instrumental approach (Berger et al., 
2007; Gao and Bansal, 2013; Hahn et al., 2010, 2015; Kleine and von Hauff, 2009) that moves sustainability beyond business motives and explores contributions that tend to go unnoticed in the instrumental logic (Hahn et al., 2010). To define the integrative view, Gao and Bansal (2013) explain that it acknowledges the integrative spatial and temporal systems in which the business operates and, thus, produces and reproduces economic, social, and environmental priorities. With this view, all parts are interconnected, and sustainability priorities are inclusive and interdependent. According to Gao and Bansal (2013), no single aspect of the sustainability proposition can be viewed in isolation, and no one priority is dominant over another.

The empirical findings regarding this integrative view began with seminal research that outlined an agenda for integrating social and environmental priorities into business practice (Shrivastava, 1995). Thereafter though, only limited, occasional studies explored methods to achieve such integration, such as proposals of sustainability-based performance measures (Schaltegger and Wagner, 2006) and quantification tools to ensure distributive equality (i.e., equal distribution among sustainability priorities) (Kleine and von Hauff, 2009). More recently, explorations of the preconditions for sustainable corporations (Baumgartner and Ebner, 2010) note the influence of cultural elements that result in effective corporate sustainability (Linnenluecke and Griffiths, 2010) or identify environmental performance measures (Delmas and Blass, 2010). Gao and Bansal's (2013, p. 244) formal definition - “this integrative logic refers to an approach to business sustainability that recognizes and embraces the contradictions among the financial, social, and environmental dimensions of business and seeks solutions for the system of interrelated elements"-is widely accepted (Bansal and Song, 2016). However, empirical research into the microfoundations (i.e., individual-level analyses of managerial motives and orientations) of both integrative and instrumental logics of sustainability remains limited. 


\section{Individual-level Considerations of the Integrative and Instrumental Views}

Little is known about the dynamics of the integrative and instrumental view at the individual level. Developed at the organizational level, the types have been used as an explanatory tool for individual behavior (Hahn et al., 2015; Montabon et al., 2016) without any understanding of the individual-level dynamics that underpin such positions. The blurring of levels has meant that there is no in-depth empirical understanding about the interaction between the organizational view and the individual-level view, whether leaders' views are always concurrent with those of their organizations, and what the motivational underpinnings of those holding various views are.

Other research streams propose that, at the individual level, there are two main orientations that could drive corporate sustainability. First, business motives relate directly to the financial benefits associated with pursuing social and environmental activity. Business motives involve corporate self-interest, such as legitimacy (Bansal and Clelland, 2004; Driscoll and Crombie, 2001; Prakash, 2001). Second, there are normative motives (Bansal and Roth, 2000; Hahn, 2004; Morrow and Rondinelli, 2002; Takala and Pallab, 2000; Wulfson, 2001), which include corporate-level factors that overlap with corporate social responsibility (Amaeshi and Adi, 2007; Lantos, 2001). Anecdotally, business motives are more closely aligned with the instrumental view (Amaeshi and Adi, 2007; Garriga and Melé, 2004), whereas normative motives are usually associated with the integrative view (Gao and Bansal, 2013). However, more research is needed to delineate the complex interconnections across sustainability views and motives.

In addition, the environmental psychology literature provides helpful insights for identifying potential individual-level motives (Cho et al., 2013; Greaves et al., 2013; Kaiser et al., 2018; Steg and Vlek, 2009; Steg et al., 2014; Van der Werff et al., 2013). For example, Robertson and Carleton (2018) identify environmental leadership as an antecedent of pro- 
environmental employee behavior, and Van der Werff et al. (2013) conclude that individuals' environmental/social self-identity mediates the relationship between their biospheric values and their behavior. They also suggest that interventions targeting environmental self-identity may promote environmental/social behavior more effectively than interventions targeting biospheric values because the former are easier to change. As an important question for future research, they ask whether environmental self-identity can be changed more easily than values (e.g., by influencing past behavior or reminding people of their past proenvironmental actions) and whether campaigns or policies that address environmental selfidentity actually result in pro-environmental actions.

We also consider the contributions of two studies that pioneered research on business and normative motives in corporate sustainability: Bansal and Roth (2000) and Hahn and Scheermesser (2006). With a qualitative study, Bansal and Roth (2000) examined the motivational and contextual factors that explain ecological responsiveness, driven by an effort to understand why, at the turn of the millennium, some companies decided to respond to environmental factors, while others did not. They analyzed a variety of motives, including legitimization, stakeholder pressures, economic opportunities, and ethical motives; across a sample of 53 companies, they specified competitiveness, legitimization, and ecological responsibility as the primary motives for ecological responsiveness. Building on these findings, Hahn and Scheermesser (2006) examined approaches to corporate sustainability in 195 German companies, which reveal a mixture of business and ethical motives for pursuing corporate sustainability (e.g., ecological responsibility, image, cost savings, social responsibility, profit growth). That is, both studies demonstrate that business and normative reasons together motivate the pursuit of social and environmental sustainability, a finding that should advance organizational scholars' understanding of the motivational basis for adopting either an integrative or an instrumental logic. Bansal and Roth (2000) concluded that business 
motives were more common because, across the organizations they sampled, motives associated with profit generation were more widespread. Hahn and Scheermesser (2006) added that normative reasons were more closely associated with organizations that exhibit strong corporate sustainability performance. Differentiating business and normative motives thus provides an initial basis from which to explore the various reasons that propel instrumental and integrative managers toward corporate sustainability.

Like the two views of sustainability, the multiple orientations that drive sustainability at an individual level suggest several points of interest. Specifically, understanding is required around whether the orientations of organizational leaders fit the expected normative mode associated with integrative sustainability, and conversely, the business mode associated with instrumental sustainability. Furthermore, we seek to understand whether the sustainability logics of organizations are congruent with the individuals that lead these organizations, or whether the integrative and instrumental view may be embodied in contrast to the organizational view. Thus, our research questions are as follows:

Research Question 1: When examining corporate sustainability outcomes, do leaders of higher performing organizations generally hold a normative-based integrative view?

Research Question 2: When examining corporate sustainability outcomes, do leaders of lower performing organizations generally hold a business-based instrumental view?

Research Question 3a: If discrepancies exist, what are they?

Research Question 3b: If discrepancies exist, why do they occur?

\section{Method}

The Australian Forestry and Wood Products Industry was chosen because the industry needed to be one in which sustainability was highly salient, yet organizational corporate sustainability performance in the industry varied. This would make it easier to distinguish between higher performing (integrative) organizations and lower performing (instrumental) 
organizations. The forestry and wood products industry in Australia provided this setting (The Wilderness Society, 2014). The Australian government is heavily involved in regulating the industry for environmental and social performance, with the majority of businesses reverting to regulations when operating. However, a small number of businesses have set themselves apart through achieving independent third-party certification and adopting market-leading sustainable forestry processes. The study sought to gather a combination of status quo and higher performing businesses in order to assess whether the leaders of their organizations adopted the expected instrumental or integrative views of sustainability. The industry consists of four distinct levels: Level 1 forest managers, Level 2 primary processors (e.g., sawn timber), Level 3 secondary processors (e.g., paper and printing, panel, and boards), and Level 4 wholesalers. We focus on levels 1-3 due to their proximity to the relevant natural resource.

\section{Research Strategy and Sample}

The research sought to identify two groups of companies. The first would need to demonstrate market-leading social and environmental contributions, while the second would only adhere to social and environmental practices that are in line with the industry status quo. Then, the managers of these organizations would be interviewed, and their orientations towards sustainability compared with their company's performance. Accordingly, we adopted an instrumental case study approach because this investigation meets two key criteria for using this methodology: (1) producing findings that are robust and (2) reflecting the systemic complexity of sustainability management (Eisenhardt and Graebner, 2007; Stake, 1995). The design uses in-depth qualitative methods to explicate complex topics; for this study, we deployed it across a large number of case organizations to generate robust findings.

We used purposive sampling to identify the organizations for the study. Initially, we emailed 139 businesses and 39 state forestry bodies with information about the study, with an 
invitation to participate, to which we received over 40 responses for voluntary participation. We managed inclusion based on achieving demographic spread which ensured a mixture of small, medium, and large organizations, as well as companies with varying certification levels and those that operated in different segments of the industry. Table 1 provides an overview of the sample.

(Insert Table 1 about here.)

Due to the study being voluntary, the sample includes a high number of strong performers in corporate sustainability who sought to demonstrate their social and environmental contributions. This was most clearly demonstrated through the high number of independently certified organizations involved in the study. The two main independent certification standards in Australia are the Australian Forestry Standard (AFS) and the Forestry Stewardship Council (FSC) certification, which are both internationally recognized standards (Greenpeace International, 2014). Independent third-party certification is voluntary in most forestry industries across the world, with only around $10 \%$ of the world's total forestry area covered by certification (Lawrence, 2011), and within Australia itself only 10.5 million hectares being certified, representing just under $9 \%$ of the total forest area in the country (Institute of Foresters of Australia, 2018). Of the 25 companies involved in our study, 17 of them had third-party certification, indicating a skew towards stronger performing organizations. Despite this, all organizations were included to ensure we had saturation across both effective and status quo organizations. Since the purpose of the study was to find examples of discrepancies in logics between organizations and their managers - rather than the identification of generalizable principles of such logics_-inclusion of these companies added further cases that could be examined for anomalies.

The primary data collection tool was interviews, for which organizations were asked to provide their most senior managers for the study. We sought senior executives who deal 
with corporate sustainability issues as they represent the reality makers of organizations (Fineman, 1996; Wright and Heaton, 2006). The participants interviewed were either primary managers (18 participants) or, at most, one hierarchical level below the top management position (14 participants). Table 2 details the organizational roles and positions of all 32 study informants.

\section{(Insert Table 2 about here.)}

The interviews typically lasted 45-60 minutes and were based on an interview schedule of 52 questions. The 52 questions were pared down to 48 after the pilot study. The interview schedule had three main sections, asking societal, organizational, and individuallevel questions pertaining to instrumental and integrative corporate sustainability. In addition, the interviews elicited information about strategies to respond to sustainability challenges. Data from the in-depth case (organizational) analysis helped us understand the interviewees' work settings and any of their unique contributions to their employer.

The 32 in-depth interviews were supplemented with a desk review of 187 research artifacts from other sources, such as websites, company documents, and online articles, in conjunction with independent third-party industry certifications. Any documents available were analyzed in depth before each personal interview, according to the first three pages of results when searching the company's name on Google. Several themes emerged, mainly describing organizational factors, although in many cases the themes also highlighted examples of the interviewees' contributions to corporate sustainability.

\section{Data Analysis and Coding}

The analysis needed to be able to separate organizations that had stronger performance in corporate sustainability from those that demonstrated status quo performance. Additionally, the analysis also needed to group individuals into categories showing (a) whether managers held an instrumental or integrative view and (b) whether data indicated if, 
individually, managers were active contributors to corporate sustainability or not. Qualitative typology analysis was used for this task, which has been adopted in business research including prior sustainability studies (Abouzeedan \& Busler, 2004; Olorunniwo \& Hse, 2006; Skinner et al., 2014) to classify groups of cases or participants into common or differentiating groups (Given, 2008). Combining theoretical background with empirical support is essential for creating meaningful types (Kluge, 2000; Wahl, 2013), and in line with the abductive approach proposed by Dubois and Gadde (2002), the analytic framework used to view findings involved articulated preconceptions, shaped by constant interactions between interview and document observations and relevant integrative and instrumental theory. The following stages were applied:

1) Stage 1: Develop themes from documents (D.themes) and interviews (I.themes) for each organization and participant;

2) Stage 2: Collate themes under preset type dimensions and assign ratings;

3) Stage 3: Use the themes and scores to draw comparisons and conclusions.

The themes that were used to form the typologies are summarized below. Table 3 provides an overview of the themes and data sources.

(Insert Table 3 about here.)

The type dimensions reflect the major constructs of interest for the study, which seeks to differentiate between organizations that are stronger and weaker corporate sustainability (CS) performers. Once the organizational setting is understood, the analysis then identifies whether the managers of these organizations hold an instrumental or integrative view. As a point of interest, we also developed typologies that assessed the consistency of managers' espoused orientations and the level of sustainability-based activity of each manager to validate their claims. Each type dimension is detailed below. 
Type Dimension 1—organizational corporate sustainability effectiveness. The differentiation between effective and status quo organizations was informed by third-party certifications, evidence from documents analysis (including websites, media releases, company profile information, etc.), and interview themes (see Table 3 for more details). These key sources were combined to assign effective and status quo typologies for case organizations as follows.

Effective CS organization. An effective organization made beyond-business contributions to social and environmental value, which needed to be demonstrated through strong evidence of CS activity beyond industry requirements. Third-party certification was considered important because it comes at a significant cost and effort to the organizations and is not a requirement to operate in the industry. It was expected that effective CS organizations would demonstrate their commitment through organizational goals, aims, contributions, and their marketing material; therefore, this was taken into consideration when assigning this classification.

Status quo CS organization. Organizations that showed no evidence of going beyond-business motivations in their social and environmental priorities. These businesses operated within the relevant forestry laws in Australia, which themselves are designed to ensure sustainable forestry; however, companies in this typology showed no evidence of going beyond these regulatory requirements.

Type Dimension 2 -individual sustainability orientation. After organizational classifications were assigned, we analyzed the individual characteristics of each interviewee for either instrumental or integrative logics. The criteria for differentiating between these two logics came from Hahn et al. (2015) and Gao and Bansal (2013). Participants of both orientations often registered in the same code; for example, both integrative and instrumental participants registered strongly in I4: "Social/environmental factors part of the business plan" 
(see Table 7). To distinguish between the two orientations, I3 "Social/environmental progression beyond the business plan" proved pivotal because it confirmed each participant's intent to advance all three corporate sustainability priorities. Of similarly high importance were codes I22 and I23, which identified when a participant would link normative (environmental, social-altruistic) logics to sustainability. It is important to note that Type Dimension 2 reflects an orientation, not performance. Thus, we established the two logics as follows.

Integrative logic. Participants espoused a progressive view of social and environmental corporate sustainability throughout the interview. They demonstrated an intent to advance all three priorities simultaneously, integrating the social and environmental priority equally into the business. Statements were required to show the participant's intent to go beyond the business/profit logic. An example is provided below:

"At the end of the day, sustainability has to win and that's our blanket rule, silviculture needs to win out, so you can't go through and start being unsustainable. You can't destroy the forests to make money, in the short term [that's] better economically, but [for the] forestry resource long term, it's not good" (Organization 8 , Participant 1)

In addition to examining the integrative logic, the analysis recorded instances where participants would link sustainability initiatives to either environmental or social-altruistic reasons. Ecological reasons included ecological responsibility, conservation, and preservation, whereas social-altruistic reasons included social responsibility, donations, and community activity.

Instrumental logic. Throughout the interviews, these participants linked social and environmental priorities solely to business reasons. They may have generated value across all 
three corporate sustainability priorities, but this theme reflects the participant's intent, so a business logic results in an instrumental classification. An example is provided below:

"Every decision we make, operationally, would revolve around two key things; money, and what we need to do to keep perception good environmentally and keep as low profile as possible” (Organization 22, Participant 1).

In addition to examining for an instrumental orientation, the analysis also recorded instances where participants would link sustainability to the organization's business plan. The logic would include factors such as image, cost savings, employee motivation, customer demands, opportunity of new business fields, revenue growth, demands of capital providers, demands of societal stakeholders, or response to political pressure.

Type Dimension 3-consistency of corporate sustainability orientation. This dimension assessed the individual's overall consistency of their espoused orientation. Participants expressed varying reasons for pursuing sustainability (integrative or instrumental), but rather than measuring reasons or motivations, this theme seeks to gauge the consistency of the informant's logic. The measure reflects the number of times the participant repeated the same rationale for pursuing sustainability during the interview. That is, in different stages of the interview, participants had several opportunities to explain why they pursued sustainability. If the provided rationale was confused and/or inconsistent, we classified them as inconsistent on this measure. Instead, if participants repeated a consistent rationale (three times or more), we assigned them a consistent rating. Participant 1 in Organization 1 repeated the rationale for pursuing sustainability and scored highly, as these quotes reveal:

Quote 1: "Certainly the main goals and values [of the company] are around optimizing enterprise value, and maximizing returns to investors and focusing on the three pillars." 
Quote 2: "At the end of the day I could say financial is important, having said that, if we are giving great returns but not acting in a proper way, then it's not going to be acceptable. So, it's not going to be sustainable, if you're not matching the environmental impact, we won't be sustainable, one can't happen without the others." This type dimension would show the authenticity and consistency of the logic, providing a good indicator of the strength of their orientation.

Type Dimension 4 -individual sustainability activity. This dimension reflects actions by a participant who makes social and environmental sustainability contributions to the business. It does not record any organizational-based activity, but instead indicates the specific contributions that the individual made, such as examples of compliance-based or reform activity that could improve the social and environmental standing of the organization. If participants gave multiple (typically, three or more) specific examples of their individual contributions, they were classified as active. If participants could not name specific examples, or could only provide ad hoc answers, they were assigned a status quo rating. For example, an active participant (Participant 2, Organization 1) noted:

Quote 1: “[I've] been proactive with encouraging us to control pine wildlings, and stopping weeds from invading our plantations and propagating effectively."

Quote 2: "Certainly, supported quite strongly the consideration of wildlife above and beyond what used to be the standard practice."

Quote 3: "The other thing I've done is I've been involved with the improvement of probably three of our plantation paddocks...."

Quote 4: “... and I've been involved in getting funding to improve getting rid of weeds and removing harmful factors of $50 \%$ of those areas." 
Many interviewees were members of organizations that were strong corporate sustainability performers. TD4 helped to differentiate between those that simply complied with organizational processes and those that made active contributions.

\section{Findings}

The analysis showed there were 19 effective and 6 status quo organizations, representing a high number of companies that are strong performers in corporate sustainability. Table 4 shows the demographic characteristics of both types of organizations.

(Insert Table 4 about here.)

The study identified a total of 15 managers with an integrative view, and 17 who held an instrumental view of sustainability. Although all integrative participants were found within effective organizations, the instrumental participants were spread among both the effective and status quo companies. Table 5 shows the distribution of managerial logics across both organization types. Several key themes are discussed below.

(Insert Table 5 about here.)

\section{Theme 1: Effective Organizations hosted all Integrative Participants}

The study identified 19 organizations that showed strong performance in corporate sustainability. These companies were of varying organizational size and ownership structures (see Table 4). Of these organizations, 17 held independent third-party certification. The two organizations that did not have third-party certification demonstrated a long history of social and environmental contributions. One of these organizations $(\mathrm{O} 10)$, run by a sole manager, is currently represented on two local conservation boards and had previously been given state and national awards for conservation practices, including the Land Care Hall of Fame in Australia. The second organization without certification (O11) is a forestry consultancy firm, which was similarly represented on three state-based conservation boards (across two different states). Due to the reputation of the owner, the company was used to form the 
forestry code of practice in two Australian states, while also being heralded as the pioneer for the restoration and management of one of Western Australia's at-risk tree species, which has now been turned into a sustainable forestry resource.

The effective organizations housed all 15 managers who espoused an integrative logic towards sustainability. These managers adopted a strong position in prioritizing the equal progression of social, environmental and economic values:

[Demonstration of equal weighting] "I would rank them [the sustainability pillars] equally; social, environmental, and economic.... (Organization 1, Participant 1) "We stayed not-for-profit, because the majority of our staff wanted it that way. We are all committed to dragging the industry into a sustainable future." (Organization 12, Participant 1)

Additionally, all managers that were classified as adopting the integrative view were able to demonstrate strong personal contributions that they have made to corporate sustainability, separate from routine organizational processes:

[Chief Executive Officer exhibiting corporate sustainability measures taken] "We give input into certain areas, we are on the board of [Australian state] forestry board and we're trying to give as much input as we can....We are looking to bio energy. We are looking at these options to improve, we are exploring some of these to be sustainable in the long run." (Organization 3, Participant 1)

[Managing Director exhibiting corporate sustainability measures taken] "[The] decision to move to certification, without a doubt, to meet and comply with a standard, it probably made us step up even more. We weren't acting irresponsibly prior, but a higher level of focus has raised the bar." (Organization 1, Participant 1) All participants identified as integrative also showed consistency in their logic (Table 5), meaning that they repeated integrative principles throughout the interview. These 
participants also espoused stronger social-altruistic and ecological links to sustainability compared to the instrumental participants, as summarized in Table 6. Of the 15 integrative participants identified, 7 were primary managers, while 8 were secondary managers.

(Insert Table 6 about here.)

\section{Theme 2: Status quo Organizations Included Only Instrumental Participants}

There were six organizations identified in the study that were classified as status quo, which operated within the required regulatory framework in Australia, however demonstrated little evidence of going beyond this to generate market-leading social and environmental outcomes. As shown in Table 4, none of these organizations had third-party certification. Additionally, unlike the high-performing organizations that represented a mixture of organizational size and ownership structure, all status quo organizations were small, locally owned businesses.

Of the six participants interviewed from these organizations, all held an instrumental logic towards corporate sustainability, and pursued social and environmental contributions for perceived financial payoff, reputational payoff, or for risk aversion:

[When discussing the reasons for pursuing sustainability], "It's [about] investment return to shareholders, but on a long-term basis ... if we lose reputation we lose business." (Organization 1, Participant 3)

“Environmentally, well it's extremely regulated so we need to be as environmentally sound as we can." (Organization 1, Participant 3)

These managers demonstrated that the pursuit of sustainability was primarily for reputational or other business reasons, unlike the integrative group which sought to advance the three sustainability priorities concurrently.

\section{Theme 3: Effective Organizations Housed Several Instrumental Managers}


The findings showed that, within the effective organizations, there were also 11 interviewees who espoused a strong instrumental logic towards sustainability (Table 5). Of these 11 managers, two distinct groups emerged — one that represented a group of highly motivated (largely primary) managers and a second group mainly made up of (largely secondary) managers that demonstrated fewer social and environmental contributions. The latter, represented by $\mathrm{O} 1 \mathrm{P} 3, \mathrm{O} 7 \mathrm{P} 1, \mathrm{O} 7 \mathrm{P} 2, \mathrm{O} 13 \mathrm{P} 1, \mathrm{O} 15 \mathrm{P} 1$, and $\mathrm{O} 20 \mathrm{P} 2$, indicated a profit priority orientation, despite occupying roles in organizations that generate leading social and environmental outcomes.

[When asked about the priorities of the company] "Profit [...] to be competitive, and grow in size." (Organization 7, Participant 1)

Of this group, only O13P1 was a primary manager; however, the factory that he ran was recently acquired by a parent company, who had installed a set of sustainability policies outside of his control. Although these managers were all part of effective organizations, each of these managers exhibited limited individual sustainability activity, with little evidence provided that they made contributions to social and environmental value beyond normal business processes. When queried about their contributions, these participants diverted often to company processes to explain how they have contributed.

[When asked for examples of social and environmental contribution] "I wouldn't say me in particular, something I pride myself on is relying on each other, we consult and we come up with solutions." (Organization 1, Participant 3)

Additionally, these participants did not show a clear and consistent logic toward sustainability; instead, they often espoused multiple conflicting reasons and approaches toward corporate sustainability.

A second group, consisting of O5P1, O7P3, O15P1, O16P1, O23P1 and O25P1, exhibited very different characteristics. Each of these participants, with the exception of 
$\mathrm{O} 15 \mathrm{P} 1$, was a primary manager. These managers registered personal contributions to environmental and social outcomes in their business, which went beyond business logic, and matched, if not outperformed, their integrative counterparts. These actors stated their strong instrumental views toward sustainability:

[When asked about the goals of the company] "[We are] no charity, to make money is the simple response. It won't make money unless derived from sustainable means" (Organization 18, Participant 1)

However, they also provided examples of how they led their companies into more sustainable pathways:

“....we don't buy uncertified [timber]. We came across a pristine wood from KL, price was competitive, but because we can't get it certified we didn't feel comfortable .... I could fudge things to sell [it], but I won't." (Organization 18, Participant 1) "We are dual certified .... Certification is just part of the process to ensure we have the right things." (Organization 18, Participant 1)

Additionally, these participants register a strong rating for the consistency of their sustainability orientation, meaning that they repeated a consistent reason for pursuing sustainability throughout their interview. O5P1 demonstrated this when first asked what the goals of the organization were:

"We are trying to achieve long term and sustainable return for our shareholder, whilst insuring we're customer focused and support our people and the communities which we are a part of." (Organization 5, Participant 1)

Then, when asked what the priorities of the business are:

"I think the first [and] most important, [is the] shareholder, so that's first. The second is about the people and then our customers, and then our communities." (Organization 5, Participant 1) 
The examples provided, combined with the consistency of their logic, indicated active contributions to social and environmental value. This assumption is further solidified in that all of this group (except $\mathrm{O} 15 \mathrm{P} 1$ ) are primary managers, who lead and guide organizations that are currently operating above industry standards for generating social and environmental value. For the sake of further analysis, these six participants are described as the effective instrumentalists.

\section{Theme 4: Effective Instrumentalists More Strongly Believe that Social and Environmental Contributions Result in Business Outcomes}

With the purpose of seeking to explain the motivation of the effective instrumentalists, we undertook further examination of the reasons they gave for pursuing sustainability. The additional analytic step involved identifying the number of times that participants linked social and environmental contributions to their business plan. The frequency of these instances was recorded for each participant, with the spread across all key groups shown in Table 7. Although based only on a small sample, the effective instrumentalists more frequently linked social and environmental contribution to their business plan.

\section{(Insert Table 7 about here.)}

\section{Discussion}

In this study, most managers' views matched, as expected, the corporate sustainability logics of their organization, with all integrative participants being housed within effective organizations, and the status quo organizations housing only instrumental participants. The findings indicate that the major claims about the integrative and instrumental views hold true when applied to individual managers. The most central of these claims is that the integrative view results in better social and environmental outcomes for business (Gao and Bansal, 2013; Hahn et al., 2015; Jones, 2016; Le Roux and Pretorius, 2016). All 15 participants classified as 
integrative worked in effective organizations, and the individuals themselves were personally active when it came to social and environmental contributions. These findings provide support for the core theoretical claim that managers with an integrative view produce stronger social and environmental outcomes in business - at least according to the study participants' assertions in our interviews.

Nevertheless, 11 instrumental participants were employed in effective organizations. Six of these participants were shown to be active in their personal contributions and showed strong consistency in their sustainability logic. These six participants, five of whom were primary managers leading their organizations, were termed effective instrumentalists as they demonstrated equal, if not more, social and environmental activity compared to their integrative counterparts. The presence of the effective instrumentalists within organizations that were generating strong social and environmental performance presented a conundrum for the integrative and instrumental view of sustainability because the findings suggest there can be inconsistency between an organization's sustainability view and the personal orientations of the managers running the business.

The phenomenon of effective instrumentalists had several underlying assumptions. The study was conducted in an industry that was focused on environmental performance. The mandatory government regulations underpinning the industry and expectation of the public were geared toward environmental responsibility. Additionally, the forestry businesses we studied were often the primary employers within the rural towns in which they operated and would come under scrutiny from regional governments concerning the rights of their employees, which heightened the need for strong social performance. Thus, the effective instrumentalists recognized the need for social and environmental performance from a strategic perspective. Our data indicate they registered the highest frequencies of any surveyed group in linking social and environmental performance to their business plan (Table 
6). Our findings indicated that, under these industry conditions, effective instrumentalists believed that social and environmental contributions would lead to effective business outcomes, suggesting that effective instrumentalists perceived sustainability-based performance as a means to improve economic performance. This goes some way toward explaining how those with an instrumental view operated within effective organizations and demonstrated sustainability activity in line with their integrative counterparts.

Worth citing is that, of the 11 instrumental participants housed within effective organizations, six were classified as effective instrumentalists, with five other participants not fitting this categorization. These were study participants who were employed within effective organizations, but showed little or no individual-level social or environmental activity. These participants would often cite organization-level practices as their personal contribution to social and environmental goals. Of these five managers, four were secondary managers and were not directly responsible for leading their organization. This may indicate that within integrative organizations, the inconsistency between the organizational view and individual view may increase further down the organizational hierarchy. It may be the case that such organizations are employing a significant number of instrumental participants whose views are at odds with the organization's corporate sustainability logic.

\section{Theoretical and Meta-theoretical Implications}

More broadly, our findings suggest that empirical outcomes may not always be consistent with sustainability researchers' rejection of capitalist values of instrumental business reasoning or economic self-interest (Rand, 1964; Schumpeter, 1947). The findings do not, in their totality, reflect the typical ideological commitments of researchers of corporate sustainability and corporate social responsibility more generally (Orlitzky, 2011), which would have led to a different sorting of participants than that shown in Table 5 and no category of effective instrumentalists. In their insistence on the superiority of the integrative 
view, corporate sustainability principles generally instantiate Leftwing political ideologies (Orlitzky, 2015), reflecting the "red/green" values espoused by the intellectual elites (Hayek, 1948; Nozick, 1997; Schumpeter, 1947). ${ }^{1}$ In recent decades, the community of social scientists has become even more of a bastion of Leftwing "red/green" values (Duarte et al., 2015). Thus, it seems unsurprising that most academics predict relationships that reflect their own objections to the profit motives of capitalism and instead advocate corporate governance elements of "sustainable" organizations working for a "better society" (see also Locke, 2006). Christiana Figueres, the Executive Secretary for the UN Framework Convention on Climate Change, similarly has expressed her political-ideological commitment to socialist causes that, in various UN sustainability regulations, question and undermine the profit motive, selfinterest, and other core features of free-market, profit-based capitalism (Durden, 2017).

From another, ethical perspective, these values reflect an "expanded sense of justice" (Koger and Du Nann Winter, 2010), which incorporates thinking about all species, not just humans, hand in hand with the ideological and educational perspectives we have outlined. Many intellectuals argue that this "higher" thinking is required for future human developmental progress to advance ideas for resolving current environmental and social predicaments, yet it is not necessarily incompatible with profit motives (Borland and Lindgreen, 2013; Porritt, 2007; Zohar and Marshall, 2000).

\section{Practical Implications}

This study also has several practical implications for businesses looking to build upon various sustainability views. For businesses seeking to adopt an integrative view, the findings show that, sometimes, staff can hold views that contrast with organizational corporate sustainability logics. The identification of beyond-business integrative logics at an individual level may go some way toward ensuring compatibility for companies wishing to take the integrative pathway - a step which, as our study suggests, is also associated with positive 
social and environmental outcomes. However, our study indicated that the instrumental and integrative view was not the sole determinant of organizational corporate sustainability performance. In fact, assessing individuals' commitment to corporate sustainability (even if for business reasons) and their track record of social and environmental performance may be a better indicator of future outcomes.

\section{Conclusions}

The evidence from our study provides some support for the integrative and instrumental framework at both individual and organizational levels of analysis, currently advocated in the corporate sustainability literature. Generally, managers can be classified as having predominantly an instrumental or an integrative view on sustainability; more often than not, integrative managers generate better social and environmental outcomes in business. The exploratory findings also confirm that the reasons each group pursues sustainability match extant theory, with integrative proponents holding stronger normative positions.

Several instrumental participants exhibited their market-leading corporate sustainability performance, which may be indicative of an industry-specific phenomenon that requires further exploration. Further studies (e.g., larger samples, cross-industry studies) are needed to validate these findings and test their generalizability, with the results so far indicating that the effective instrumentalists are a phenomenon that may, however, only occur in sustainability-oriented industries. Industries with a weaker business case for corporate sustainability may not match these patterns.

At the organizational level, the distinction between the instrumental and integrative views can be useful for generalization purposes. However, the discovery of exceptions to this rule also suggests that the assumptions underpinning these categories do not always hold in practice. Perhaps most important, the results show that managers with an instrumental or an integrative logic can contribute and generate market-leading social and environmental 
outcomes for business. For academics and advocates of sustainability, this study demonstrates the importance of developing a narrative that is inclusive of both the business case and more moral-normative positions for environmental and social pursuits. This field of inquiry should not fall into the trap of downplaying the importance of (instrumental) profit motives that, even if they support pro-environmental actions in some organizational contexts, may contradict sustainability researchers' theoretical, political, or ideological commitments. 


\section{References}

Abouzeedan, A., \& Busler, M. (2004). Typology analysis of performance models of small and medium-size enterprises (SME). Journal of International Entrepreneurship, 2(1), 155-177.

Amaeshi, K., \& Adi, B. (2007). Reconstructing the corporate social responsibility construct in Utlish. Business Ethics: A European Review, 16(1), 3-18.

Angus-Leppan, T., Benn, S., \& Young, L. (2010). A sensemaking approach to trade-offs and synergies between human and ecological elements of corporate sustainability. Business Strategy and the Environment, 19(4), 230-244.

Bansal, P. (2005). Evolving sustainability: A longitudinal study of corporate sustainable development. Strategic Management Journal, 26(3), 197-218.

Bansal, P., \& Clelland, I. (2004). Talking trash: Legitimacy, impression management, and unsystematic risk in the context of the natural environment. Academy of Management Journal, 47(1), 93-103.

Bansal, P., \& Roth, K. (2000). Why companies go green: A model of ecological responsiveness. Academy of Management Journal, 43(4), 717-736.

Bansal, P., \& Song, H.-C. (2016). Similar but not the same: Differentiating corporate responsibility from sustainability. Academy of Management Annals, 11(1), 105-149.

Barnett, M., \& Salomon, R. (2012). Does it pay to be really good? Addressing the shape of the relationship between social and financial performance. Strategic Management Journal, 33(11), 1304-1320.

Barney, J. B. (1991). Firm resources and sustained competitive advantage. Journal of Management, 17(1), 99-120

Barney, J., Wright, M., \& Ketchen, D. J. (2001). The resource-based view of the firm: Ten years after 1991. Journal of Management, 27(6), 625-641. 
Baumgartner, R., \& Ebner, D. (2010). Corporate Sustainability Strategies: Sustainability profiles and maturity levels. Sustainable Development, 18(2), 76-89.

Berger, I., Cunningham, P., \& Drumwright, M. (2007). Mainstreaming corporate social responsibility: Developing markets for virtue. California Management Review, 49(4), $132-157$.

Borland, H., \& A. Lindgreen (2013). Sustainability, epistemology, ecocentric business and marketing strategy: Ideology, reality and vision. Journal of Business Ethics, 117(1), $173-187$.

Borland, H., Ambrosini, V., Lindgreen, A., Vanhamme, J. (2016). Building theory at the intersection of ecological sustainability and strategic management. Journal of Business Ethics, 135(2), 293-307.

Carpenter, G., \& White, P. (2004). Sustainable development: Finding the real business case. Corporate Environmental Strategy, 11(2), 17-22.

Carroll, A. \& Shabana, K. (2010). The business case for corporate social responsibility: A review of concepts, research and practice. International Journal of Management Reviews, 12(1), 85-105.

Charlo, M., Moya, I., \& Muñoz, A. (2015). Sustainable development and corporate financial performance: A study based on the FTSE4Good IBEX Index. Business Strategy and the Environment, 24(4), 277-288.

Chin, M. K., Hambrick, D. C., \& Treviño, L. (2013). Political ideologies of CEOs: The influence of executives' values on corporate social responsibility. Administrative Science Quarterly, 58(2), 197-232.

Cho, Y., Thyroff, A., Rapert, M., Park, S. \& Lee, H. (2013). To be or not to be green: Exploring individualism and collectivism as antecedents of environmental behaviour. Journal of Business Research, 66(8), 1052-1059. 
Delmas, M., \& Blass, V. (2010). Measuring corporate environmental performance: the tradeoffs of sustainability ratings. Business Strategy and the Environment, 19(4), 245-260.

Di Giuli, A., \& Kostovetsky, L. (2014). Are red or blue companies more likely to go green? Politics and corporate social responsibility. Journal of Financial Economics, 111(1), $158-180$.

Dixon-Fowler, H. R., Slater, D. J., Johnson, J. L., Ellstrand, A. E., \& Romi, A. M. (2013). Beyond "Does it pay to be green?" A meta-analysis of moderators of the CEP-CFP relationship. Journal of Business Ethics, 112(2), 353-366.

Donaldson, T., \& Preston, L. E (1995). The stakeholder theory of the corporation: Concepts, evidence, and implications. Academy of Management Review, 20(1), 65-91.

Driscoll, C., \& Crombie, A. (2001). Stakeholder legitimacy management and the qualified good neighbor: The case of Nova Nada and JDI. Business \& Society, 40(4), 442-471.

Duarte, J. L., Crawford, J. T., Stern, C., Haidt, J., Jussim, L., \& Tetlock, P. E. (2015). Political diversity will improve social psychological science. Behavioral and Brain Sciences, 38, 1-13.

Dubois, A., \& Gadde, L. (2002). Systematic combining: An abductive approach to case research. Journal of Business Research, 55(7), 553-560.

Durden, T. (2017, Feb. 3). U.N. official admits global warming agenda is really about destroying capitalism. Zero Hedge website. Last accessed on13 Feb. 2017 at http://www.zerohedge.com/news/2017-02-03/un-official-admits-global-warmingagenda-really-about-destroying-capitalism

Dyllicks, T., and Hockerts, K. (2002). Beyond the business case for corporate sustainability. Business Strategy and the Environment, 11(2), 130-141.

Eccles, R., Ioannou, I., \& Serafeim, G. (2014). The impact of corporate sustainability on organizational processes and performance. Management Science, 60(11), 2835-2857. 
Ehnert, I., Harry, W., \& Zink, K. (2014). Sustainability and HRM. In Sustainability and Human Resource Management (pp. 3-32). Springer Berlin Heidelberg. Retrieved from http://link.springer.com/chapter/10.1007/978-3-642-37524-8_1

Eisenhardt, K. M., \& Graebner, M. E. (2007). Theory building from cases: opportunities and challenges. Academy of Management Journal, 50(1), 25-32.

Endrikat, J., Guenther, E., \& Hoppe, H. (2014). Making sense of conflicting empirical findings: A meta-analytic review of the relationship between corporate environmental and financial performance. European Management Journal, 32(5), 735-751.

Epstein, M. J. (2008). Making sustainability work: Best practices in managing and measuring corporate social, environmental, and economic impacts. Sheffield: Greenleaf.

Fineman, S. (1996). Emotional subtexts in corporate greening. Organization Studies, 17(3), 479-500.

Friede, G., Busch, T., \& Bassen, A. (2015). ESG and financial performance: Aggregated evidence from more than 2000 empirical studies. Journal of Sustainable Finance and Investment, 5(4) 210-233.

Gao, J., \& Bansal, P. (2013). Instrumental and integrative logics in business sustainability. Journal of Business Ethics, 112(2), 241-255.

Garriga, E., \& Melé, D. (2004). Corporate social responsibility theories: Mapping the territory. Journal of Business Ethics, 53(1/2), 51-71.

Given, L. (2008). The SAGE Encyclopedia of Qualitative Research Methods. 2455 Teller Road, Thousand Oaks, California 91320 United States: SAGE Publications, Inc. Retrieved from http://knowledge.sagepub.com/view/research/SAGE.xml

Greaves, M., Zibarras, L. \& Stride, C. (2013). Using the theory of planned behaviour to explore environmental behavioural intentions in the workplace. Journal of Environmental Psychology, 34(June), 109-120. 
Greenpeace International. (2014). Weaker Certification Schemes [Greenpeace]. Retrieved September 26, 2015, from

http://m.greenpeace.org/international/en/mid/campaigns/forests/solutions/alternativesto-forest-destruc/Weaker-Certification-Schemes/

Hahn, T. (2004). Why and when companies contribute to societal goals: The effect of reciprocal stakeholder behavior. Academy of Management Proceedings, 2004(1), D1D6. https://doi.org/10.5465/AMBPP.2004.13857756

Hahn, T., \& Figge, F. (2011). Beyond the bounded instrumentality in current corporate sustainability research: Toward an inclusive notion of profitability. Journal of Business Ethics, 104(3), 325-345.

Hahn, T., Figge, F., Pinkse, J., \& Preuss, L. (2010). Trade-offs in corporate sustainability: You can't have your cake and eat it. Business Strategy and the Environment, 19(4), $217-229$.

Hahn, T., Pinkse, J., Preuss, L., \& Figge, F. (2015). Tensions in corporate sustainability: Towards an integrative framework. Journal of Business Ethics, 127(2), 297-316.

Hahn, T., \& Scheermesser, M. (2006). Approaches to corporate sustainability among German companies. Corporate Social Responsibility and Environmental Management, 13(3), $150-165$.

Hart, S. L., \& Ahuja, G. (1996). Does it pay to be green? An empirical examination of the relationship between emission reduction and firm performance. Business Strategy and the Environment, 5(1), 30-37.

Hart, S. L., \& Dowell, G. (2011). A natural-resource-based view of the firm: Fifteen years after. Journal of Management, 37(5), 1464-1479.

Hayek, F. A. (1948). The intellectuals and socialism. University of Chicago Law Review, 16, $417-433$. 
Institute of Foresters of Australia. (2018). Forest certification. Retrieved June 15, 2018, from https://www.forestry.org.au/about-forestry/forest-certification

Ivory, S., \& Brooks, S. (2018). Managing corporate sustainability with a paradoxical lens: Lessons from strategic agility. Journal of Business Ethics, 148(2), 347-361.

Jones, D. (2016). The "biophilic organization": An integrative metaphor for corporate sustainability. Journal of Business Ethics, 138(3), 401-416.

Jones, T. M. (1995). Instrumental stakeholder theory: A synthesis of ethics and economics. Academy of Management Review, 20(2), 404-437.

Kaiser, F., Merten, M., \& Wetzel, E. (2018). How do we know we are measuring environmental attitude? Specific objectivity as the formal validation criterion for measures of latent attributes. Journal of Environmental Psychology, 55(February), $139-146$.

Kleine, A., \& von Hauff, M. (2009). Sustainability-driven implementation of corporate social responsibility: Application of the integrative sustainability triangle. Journal of Business Ethics, 85(4), 517-533.

Kluge, S. (2000). Empirically grounded construction of types and typologies in qualitative social research. Forum: Qualitative Social Research, 1(1). Retrieved from http://www.qualitative-research.net/index.php/fqs/article/view/1124

Koger, S. and Du Nann Winter, D. (2010). The psychology of environmental problems ( $3^{\text {rd }}$ ed.). New York: Taylor Francis.

Kozlowski, S. \& Klein, K. (2000). A multilevel approach to theory and research in organizations: Contextual, temporal and emergent processes. In K.J. Klein and S. W. J. Kozlowski (Eds.) Multilevel Theory, Research and Methods in Organizations: Foundations, Extensions and New Directions (pp. 3-90). San Francisco, CA: JosseyBass. 
Lantos, G. (2001). The boundaries of strategic corporate social responsibility. Journal of Consumer Marketing, 18(7), 595-632.

Lawrence, P. (2011). Forest certification: A small step towards sustainability. Retrieved September 11, 2015, from https://theconversation.com/forest-certification-a-smallstep-towards-sustainability-2394

Le Roux, C., \& Pretorius, M. (2016). Navigating sustainability embeddedness in management decision-making. Sustainability, 8(5), 444. https://doi.org/10.3390/su8050444

Linnenluecke, M. K., \& Griffiths, A. (2010). Corporate sustainability and organizational culture. Journal of World Business, 45(4), 357-366.

Locke, E. A. (2006). Business ethics: A way out of the morass. Academy of Management Learning \& Education, 5(3), 324-332.

Lourenço, I., Branco, M., Curto, J., \& Eugénio, T. (2011). How does the market value corporate sustainability performance? Journal of Business Ethics, 108(4), 417-428.

Marcus, A. A., \& Fremeth, A. R. (2009). Green management matters regardless. Academy of Management Perspectives, 23(3), 17-26.

Margolis, J., \& Walsh, J. (2003). Misery loves companies: Rethinking social initiatives by business. Administrative Science Quarterly, 48(2), 268-305.

Montabon, F., Pagell, M., \& Wu, Z. (2016). Making sustainability sustainable. Journal of Supply Chain Management, 2(52), 11-27.

Montiel, I. (2008). Corporate social responsibility and corporate sustainability: Separate pasts, common futures. Organization and Environment, 21(3), 245-269.

Morrow, D., \& Rondinelli, D. (2002). Adopting corporate environmental management systems: Motivations and results of ISO 14001 and EMAS certification. European Management Journal, 20(2), 159-171.

Nozick, R. (1997). Socratic puzzles. Cambridge, MA: Harvard University Press. 
Olorunniwo, F., \& Hsu, M. (2006). A typology analysis of service quality, customer satisfaction and behavioural intentions in mass services. Managing Service Quality, 16(2), 106-123.

Orlitzky, M., Schmidt, F., \& Rynes, S. (2003). Corporate social and financial performance: A meta-analysis. Organization Studies, 24(3), 403-441.

Orlitzky, M. (2011). Institutional logics in the study of organizations: The social construction of the relationship between corporate social and financial performance. Business Ethics Quarterly, 21(3), 409-444.

Orlitzky, M. (2015). The politics of corporate social responsibility or: Why Milton Friedman was right all along. Annals in Social Responsibility, 1(1), 5-29.

Orlitzky, M., Siegel, D. S., \& Waldman, D. A. (2011). Strategic corporate social responsibility and environmental sustainability. Business \& Society, 50(1), 6-27.

Porritt, J. (2007). Capitalism as if the world matters. London: Earthscan.

Prakash, A. (2001). Why do firms adopt "beyond-compliance" environmental policies? Business Strategy and the Environment, 10(5), 286-299.

Purser, R. E., Park, C., \& Montuori, A. (1995). Limits to anthropocentrism: Toward an ecocentric organization paradigm? Academy of Management Review, 20(4), 10531089.

Rand, A. (1964). The virtue of selfishness: A new concept of egoism. New York: New American Library.

Robertson, J., \& Carleton, E. (2018). Uncovering how and when environmental leadership affects employee's voluntary pro-environmental behavior. Journal of Leadership and Organization Studies, 25(2), 197-210.

Russo, M. V. (2003). The emergence of sustainable industries: Building on natural capital. Strategic Management Journal, 24(4), 317-331. 
Russo, M. V., \& Fouts, P. A. (1997). A resource-based perspective on corporate environmental performance and profitability. Academy of Management Journal, $40(3), 534-559$

Salzmann, O., Ionescu-Somers, A., \& U. Steger, (2005). The business case for corporate sustainability: Literature review and research options. European Management Journal, 23(1), 27-36.

Schaltegger, S., \& Wagner, M. (2006). Integrative management of sustainability performance, measurement and reporting. International Journal of Accounting, Auditing and Performance Evaluation, 3(1), 1-19.

Schumpeter, J. (1947). Capitalism, socialism, and democracy (2nd Ed.). New York: Harper. Shrivastava, P. (1995). The role of corporations in achieving ecological sustainability. The Academy of Management Review, 20(4), 936-960.

Siegel, D. S. (2009). Green management matters only if it yields more green: An economic/strategic perspective. Academy of Management Perspectives, 23(3), 5-16.

Skinner, D., Rocks, S., Pollard, S., Drew, G. (2014). Identifying uncertainty in environmental risk assessments: The development of a novel typology and its implications for risk characterization. Human and Ecological Risk Assessment: An International Journal, 20(3), 607-640.

Stake, R. (1995). The art of case study research. Thousand Oaks, CA: Sage.

Steg, L. \& Vlek, C. (2009). Encouraging pro-environmental behaviour: An integrative review and research agenda. Journal of Environmental Psychology, 29(3), 309-317.

Steg, L., Bolderdijk, J. W., Keizer, K., \& Perlavicute, G. (2014). An integrated framework for encouraging pro-environmental behaviour: The role of values, situational factors and goals. Journal of Environmental Psychology, 38(June), 104-115. 
Takala, T., \& Pallab, P. (2000). Individual, collective and social responsibility of the firm. Business Ethics: A European Review, 9(2), 109-118.

The Wilderness Society. (2015). "PEFC-approved" - the unsustainable stamp of approval. Retrieved September 26, 2015, from http://wilderness.org.au/pefc-approvedunsustainable-stamp-approval

Trumpp, C., \& Guenther, T. (2017). Too little or too much? Exploring U-shaped relationships between corporate environmental performance and corporate financial performance. Business Strategy and the Environment, 26(1), 49-68.

Van der Werff, E., Steg, L. and Keizer, K. (2013). The value of environmental self-identity: The relationship between biospheric values, environmental self-identity and environmental preferences, intentions and behaviour. Journal of Environmental Psychology, 34(June), 55-63.

Wahl, M. (2013). Ownership typology: Four basic human values \& will based ideal types. Research in Economics and Business: Central and Eastern Europe, 4(2), 61-83.

Wang, L., Li, S., \& Gao, S. (2014). Do greenhouse gas emissions affect financial performance? An empirical examination of Australian public firms. Business Strategy and the Environment, 23(8), 505-519.

Wernerfelt, B. (1984). A resource-based view of the firm. Strategic Management Journal, 5(2), 171-180.

Whiteman, G., Walker, B. and Perego, P. (2013). Planetary boundaries: Ecological foundations for corporate sustainability. Journal of Management Studies, 50(2), 207 336.

Wright, L. T., \& Heaton, S. (2006). Fair Trade marketing: An exploration through qualitative research. Journal of Strategic Marketing, 14(4), 411-426. 
Wulfson, M. (2001). The ethics of corporate social responsibility and philanthropic ventures. Journal of Business Ethics, 29(1-2), 135-145.

Xie, S., \& Hayase, K. (2007). Corporate environmental performance evaluation: A measurement model and a new concept. Business Strategy and the Environment, $16(2), 148-168$.

Zohar, D. \& Marshall, I. (2000). Spiritual intelligence: The ultimate intelligence. London: Bloomsbury. 
Table 1:

Organizational Demographics

\begin{tabular}{ll}
\hline Characteristics & Number of Case Organizations \\
\hline Primary Industry & 10 \\
\hline Forest managers (Level 1) & 7 \\
Primary processors (Level 2) & 8 \\
Secondary processors (Level 3) & \\
\hline Firm Size (number of full-time employees) & 10 \\
Small (0-10 employees) & 8 \\
Medium (11-99 employees) & 7 \\
Large (more than 100 employees) & \\
\hline Certification & 8 \\
None & 8 \\
Single (either AFS or FSC) & 9 \\
Dual (both AFS and FSC) &
\end{tabular}




\section{Table 2:}

\section{Organizational Positions and Roles of Study Participants}

\begin{tabular}{|c|c|}
\hline Position $(P=$ primary managers $)$ & $\begin{array}{l}\text { Number of } \\
\text { Participants }\end{array}$ \\
\hline Business Owner $(P)$ & 8 \\
\hline Managing Director $(P)$ & 5 \\
\hline Chief Executive Officer $(P)$ & 3 \\
\hline General Manager $(P)$ & 1 \\
\hline Plant Manager $(P)$ & 1 \\
\hline Environment and Certification Manager & 3 \\
\hline Production Manager & 3 \\
\hline Business/Regional Manager & 2 \\
\hline Technical Manager & 2 \\
\hline Marketing, Public Relations Manager & 2 \\
\hline Forestry Manager & 2 \\
\hline Total & $\underline{\underline{32}}$ \\
\hline
\end{tabular}


Table 3:

\section{Themes and Type Dimensions}

\begin{tabular}{|l|l|l|}
\hline Type Dimension (TD) & Classifications & \\
\hline TD 1. Organizational corporate & Status quo & \\
sustainability effectiveness & & \\
\hline Themes used to determine the typology: \\
D1. Certification/sustainability given a separate tab (Website only) \\
D2. Overall 'green' theme of the website (Website only) \\
D3. Mentions, but no strong promotion of sustainability \\
D4. Environmental/social a company goal \\
D5. The company has AFS certification \\
D6. The company has FSC certification \\
D7. Evidence of social/environmental contribution beyond business reasons \\
I1. Social/environmental sustainability part of organizational goals \\
I2. No social/environmental aspect to company goals \\
I3. Social/environmental progression beyond business plan \\
I4. Social/environmental as part of business plan
\end{tabular}

\begin{tabular}{|l|l|l|}
\hline TD 2. Individual sustainability orientation & Instrumental & Integrative \\
\hline
\end{tabular}

Themes used to determine the typology:

D7. Evidence of social/environmental beyond business reasons

I1. Social/environmental sustainability part of organizational goals

I2. No social/environmental aspect to company goals

I3. Social/environmental progression beyond the business plan

I4. Social/environmental factors part of the business plan

I22 and I23. Sustainability linked to social or environmental reasoning

\begin{tabular}{|c|c|c|}
\hline $\begin{array}{l}\text { TD 3. Consistency of corporate } \\
\text { sustainability orientation }\end{array}$ & Inconsistent & Consistent \\
\hline \multicolumn{3}{|l|}{ Themes used to determine the typology: } \\
\hline \multicolumn{3}{|c|}{ I7. Repeated articulation of logic for pursuing sustainability } \\
\hline \multicolumn{3}{|c|}{ I8. Inconsistent articulation of logic for pursuing sustainability } \\
\hline TD 4. Individual sustainability activity & Status Quo & Active \\
\hline \multicolumn{3}{|l|}{ Themes used to determine the typology: } \\
\hline \multicolumn{3}{|c|}{ D8. Documents mention personal contribution to sustainability } \\
\hline \multicolumn{3}{|c|}{ I5. Showed evidence of personal sustainability activity } \\
\hline \multicolumn{3}{|c|}{ I6. No evidence of personal sustainability activity } \\
\hline
\end{tabular}


Table 4:

Effective vs. Status-quo Organization Demographics

\begin{tabular}{|c|c|c|}
\hline Primary Industry & $\begin{array}{l}\text { Effective Organizations } \\
\qquad(n=19)\end{array}$ & $\begin{array}{c}\text { Status Quo Organizations } \\
\qquad(n=6)\end{array}$ \\
\hline Level 1 & 9 & 1 \\
\hline Level 2 & 5 & 2 \\
\hline Level 3 & 5 & 3 \\
\hline \multicolumn{3}{|l|}{ Size } \\
\hline Small & 4 & 6 \\
\hline Medium & 8 & 0 \\
\hline Large & 7 & 0 \\
\hline \multicolumn{3}{|l|}{ Certification } \\
\hline None & 2 & 6 \\
\hline Single & 8 & 0 \\
\hline Dual & 9 & 0 \\
\hline \multicolumn{3}{|l|}{ Company Type } \\
\hline Independent & $\begin{array}{c}13 \\
(\# 1,6,8,10,11,12,14,16 \\
18,20,21,23,25)\end{array}$ & $\begin{array}{c}6 \\
(\# 2,9,17,19,22,24)\end{array}$ \\
\hline Subsidiary & $\begin{array}{c}6 \\
(\# 3,4,5,7,13,15)\end{array}$ & $\mathrm{n} / \mathrm{a}$ \\
\hline
\end{tabular}


Table 5:

Organizational Distribution of Managers with Varying Logics

Managerial Logics

Organizational Outcomes

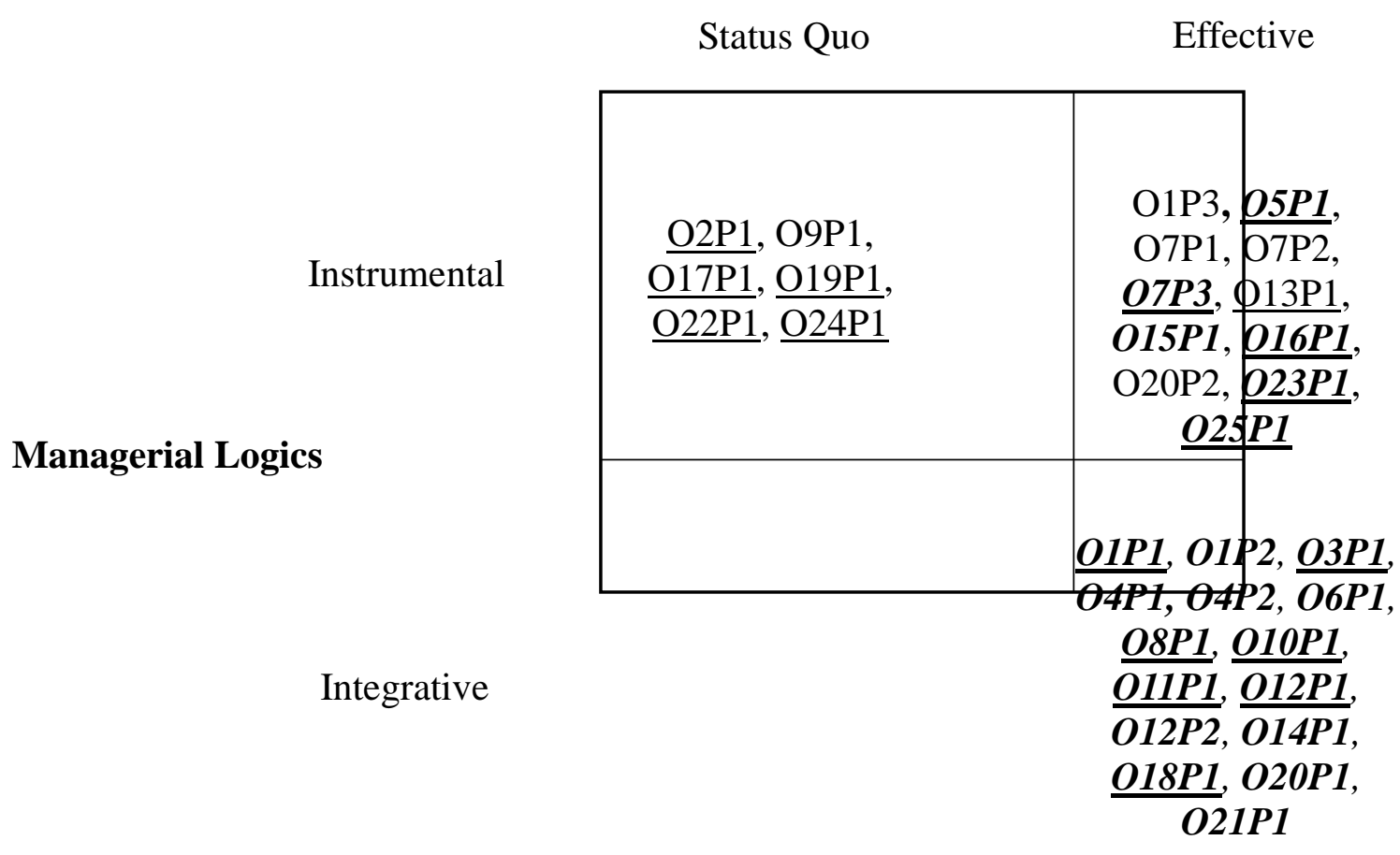

Note. underlined $=$ primary managers; bold $=$ were active in making social/environmental contributions; italics $=$ showed consistent 
Table 6:

Frequency of Linking Sustainability to Normative Reasons

\begin{tabular}{|l|l|}
\hline \multirow{2}{*}{ Integrative } & $\begin{array}{l}\text { Frequency of linking sustainability to altruistic/environmental reasoning } \\
\text { (Code I22 and I23) } \\
\text { O1P2 (1), O3P1 (2), O4P2 (2), O6P1 (2), O8P1 (5), O10P1 (2), O11P1 (2), O12P1 (1), O12P2 } \\
\text { (4), O18P1 (6), O20P1 (1), O21P1 (3) } \\
\text { Participants who cited this = 12 of } 15 \text { integrative managers } \\
\text { Frequency average across all 15 integrative managers = 2.07 }\end{array}$ \\
\hline Instrumental & $\begin{array}{l}\text { O1P3 (1), O7P2 (2), O13P1 (1), O15P1 (2), O16P1 (3), O17P1 (2), O23P1 (5), O25P1 (1) } \\
\text { Participants who cited this = 8 of 17 instrumental managers } \\
\text { Frequency average across all 17 instrumental managers = 1.00 }\end{array}$ \\
\hline
\end{tabular}




\section{Table 7:}

Frequency of Linking Sustainability to the Organizations Business Plan

\begin{tabular}{|l|l|}
\hline \multirow{2}{*}{$\begin{array}{l}\text { Frequency of linking sustainability to the organization's business plan } \\
\text { (Code I4) }\end{array}$} & $\begin{array}{l}\text { O1P1(2), O1P2 (8), O3P1 (2), O4P1 (4), O4P2 (1), O6P1 (2), O8P1 (1), O10P1 (1), O11P1 } \\
\text { (2), O12P1 (1), O12P2 (4), O14P1 (2), O18P1 (3), O20P1 (4), O21P1 (3) } \\
\text { Participants who cited this = } 15 \text { of 15 integrative managers } \\
\text { Frequency average across all } 15 \text { integrative managers = 2.66 }\end{array}$ \\
\hline Instrumental & $\begin{array}{l}\text { O1P3 (3), O2P1 (2), O5P1 (2), O7P1 (2), O7P2 (2), O7P3 (5), O9P1 (1), O13P1 (2), O15P1 } \\
\text { (2), O16P1 (3), O17P1 (2), O22P1 (2), O23P1 (4), O25P1 (4) } \\
\text { Participants who cited this = 14 of 17 instrumental managers } \\
\text { Frequency average across all } 17 \text { instrumental managers = 2.12 }\end{array}$ \\
\hline Instrumentalists & $\begin{array}{l}\text { O5P1 (5), O7P3 (5), O15P1 (2), O16P1 (3), O23P1 (4), O25P1 (4) } \\
\text { Participants who cited this = 6 of 6 effective instrumentalists } \\
\text { Frequency average across all } 6 \text { effective instrumentalists = 3.83 }\end{array}$ \\
\hline
\end{tabular}

\section{Endnotes:}

${ }^{1}$ The close association between Leftwing political orientations and strong managerial commitments to corporate social and environmental responsibility also applies to business executives themselves (Chin et al., 2013; Di Giuli and Kostovetsky, 2014). 